\title{
Integration of Agriculture Research into Manufacturing Design and Imple- mentation Projects
}

\section{Dr. Zhenhua Wu, Virginia State University}

Dr. Zhenhua Wu, is currently an Assistant Professor in Manufacturing Engineering at Virginia State University. He received his PhD in Mechanical Engineering from Texas A\&M University. His current research interests focus on cybermanufacturing, sustainable manufacturing, and adaptive digital machining.

Dr. Laban K. Rutto

Dr. Shahzad Akbar, Virginia State University

Dr. Akbar received his PhD in Electrical Engineering from Cornell University and his MS from MIT. He has many years of industrial Research and Development experience at IBM Microelectronics, DuPont and Siemens. He has also conducted research at Oak Ridge National Laboratory, NASA, Naval Research Lab and Army Research Lab. Presently, he is a tenured Associate Professor in the Engineering Department at Virginia State University. 


\title{
Integration of Agriculture Research into the Manufacturing Design and Implementation Projects
}

\begin{abstract}
Virginia State University (VSU) is an 1890 Land-Grant institution. In the fiscal year (FY) 2015, a USDA project jointly submitted by College of Agriculture and College of Engineering \& Technology was funded. The Manufacturing Engineering program at VSU is tasked to design a dryer for hop postharvest processing. In Spring 2017, a dryer project related to the grant was carried out as part of the "Manufacturing Design and Implementation" class. The joint research and education activities also address the recent USDA/NIFA Priority area "STEAM and Entrepreneurship Education". This paper details the challenges, solutions and outcomes of this design implementation project. The learning outcome from this project can improve the curriculum of 1) Product Design, 2) Manufacturing Processes, 2) Thermal Engineering, and 4) Manufacturing Automation etc. Direct and indirect assessment results illustrated that the joint activities between agriculture and engineering can provide practical problems for students. The teaching strategies for this design course also effectively helped students to achieve the desired learning outcome.
\end{abstract}

\section{Introduction}

Virginia State University (VSU) is an 1890 Land-Grant institution. In FY 2015, a USDA project jointly submitted by the College of Agriculture and College of Engineering \& Technology was funded. The VSU Manufacturing Engineering program is tasked to design a low cost and sustainable dryer for hops postharvest processing. Such a dryer prototype should be DIYed (DoIt-Yourself) by the local growers to help the small and medium hop farms. The joint research and education program between the agriculture and engineering also addresses the recent USDA/NIFA Priority Area of "STEAM and Entrepreneurship Education".

In Spring 2017, the dryer project was conducted as part of the MANE 450-“Manufacturing Design and Implementation" class. Three Manufacturing Engineering students were involved in the design of an alpha-prototype hops dryer. Through the project, students learned and gained engineering "design development skills" and "organization and team skills" [1]. The project enlightened students on time and budget constraints, the challenges of knowledge application, and the importance of outreach activities. Two students successfully graduated in Spring 2017 and the other student graduated in Fall 2017. This paper details the challenges, solutions and outcomes of this project-based course. The learning outcome from this project can improve the curriculum of 1) Product Design, 2) CAD/CAM, 3) Thermal Engineering, 4) Manufacturing Processes, and 5) Manufacturing Automation, etc.

\section{Manufacturing Design and Implementation Course at VSU}

MANE 450-Manufacturing Design and Implementation is a three-credit-hour course offered to VSU senior students. The course description for the course is " $\mathrm{A}$ mix of industry and in-house structured group projects, using process, toll, computer control, quality knowledge, and societal considerations. Projects will progress through a complete manufacturing cycle from design through implementation" [2]. 
Considering this class is instructed only for a semester, the time constraint is an obvious factor that needs to be considered for both the instructor and students. Further, there is no TA or machinist assistance in this design class. Thus, three ideas came to the instructor's mind when designing the technique learning objectives of the MANE 450: 1) Instead of focusing on the prototype product, train the student about design thinking and process, 2) Instead of helping the students to brainstorm design by trial and error, teach students scientific design theories to support the design concept generation, followed by the application of engineering approaches to embody the concepts and to analyze the design, and 3) Design the class and prototyping process as Maker activities.

Other than the technical objectives, the course also aims to train the students on 'non-technical' aspects such as professional ethics, effective communication, and team-work to enable them to become successful engineers.

From that, also linking the class with the ABET requirement, the following learning outcomes were proposed for the course:

1. The ability to apply the knowledge and tools learned in the undergraduate curriculum.

2. The ability to use constraint based engineering design process to generate design options.

3. The ability to design and conduct engineering experiments in support of design or development using literature search.

4. Ability to select appropriate tools.

5. The ability to form a team and to participate effectively, communicating clearly, and managing a task oriented project.

6. Effective individual and team communication skills, including task and schedule development using the Microsoft Project software.

7. The ability to prepare reports and presentations to disseminate the results of the project

To help students achieve the learning outcome, the MANE 450 class was conducted in three phases: Phase I-Identify customer needs and generate design concept:

This phase constitutes defining the design problem, understanding its significance and relevant factors, then collecting and analyzing data to improve understanding of the relevant factors, and finalizing the product design concept.

Phase II-Embody and analyze the design:

This phase involves detailing the Phase I design concepts using modern engineering design tools, performing engineering analysis, and presenting the design and analysis results publicly. Phase III-Prototype/experimentation and final report writing:

This phase engages to finalize the prototype product in phase II, experiment on the achieved prototype, and collect the data for the final report and presentation. Accomplish the final report and presentation, and present the final work publicly.

At the end of each phase, students were evaluated on the technique results, written reports and associated class presentations. Students were provided with a strict set of guidelines for their technique work, written and oral presentations.

In Spring 2017, there were 14 students enrolled in the class. The students were grouped into 4 projects on designing: 1) hop dryer, 2) hop baler, 3) Pioneer 3-AT robot body, and 4) DIY 3D printer. The students and instructor met on Wednesday evenings in a three-hour class. In this paper, we focus only on the hop dryer project to demonstrate the strategy on teaching such a 
manufacturing design and implementation class with limited resources. We also discuss our experiences linking agriculture research with engineering education.

\section{Design Process}

The overall design process for the dryer is illustrated in Figure 1. It has the four stages: 1) identify the opportunities and customer needs, 2) generate design concepts, 3) embody and analyze the design concepts, and 4) prototype the detailed design.

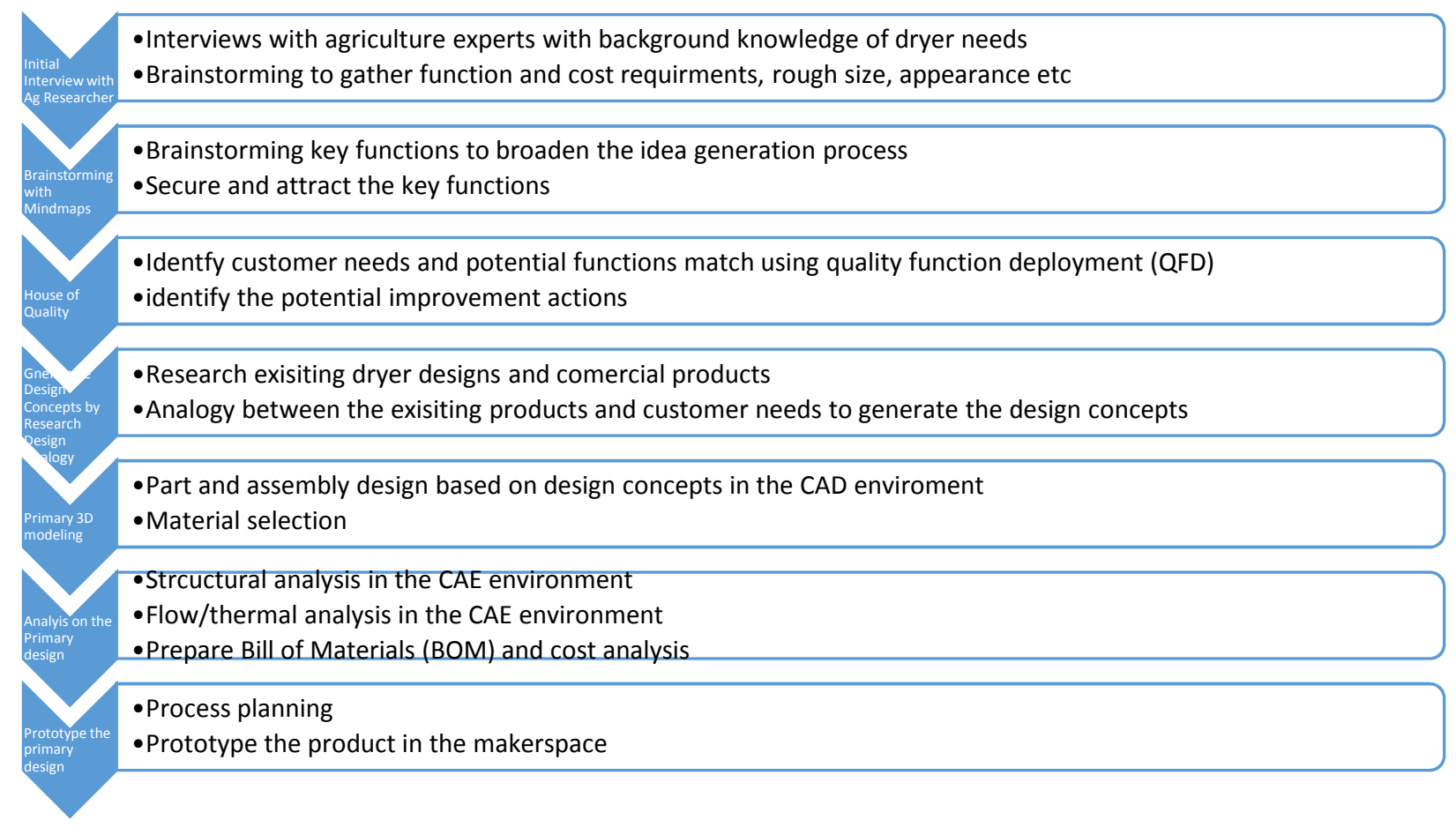

Figure 1 Overall Design Process

\subsection{Identify the needs}

Through interviews and surveys with agriculture researchers, students identified the Social, Economic and Technological (SET) needs [3] for the design project.

Socially, hop production in Virginia has been experiencing rapid growth since 2012. A survey conducted by Virginia Cooperative Extension [4] found that hop growers are facing key challenges including: 1) tools and approaches for making hop production less costly and laborious, 2) applications for cost effective postharvest processing and handling of hops, and 3) limited support from academia and industry to address the problems identified. Furthermore, although fresh hops can be directly used for brewing, local hop production has started to exceed demand for wet (fresh) hops. Farmers must consider postharvest processing alternatives including drying and baling to stabilize and extend the shelf life of their product.

Economically, by ensuring longer term availability of locally grown hops (preferred by most craft brewers), such solutions will reduce demand for imported hops to the benefit of the local economy. 
Technologically, the drying process will need to remove about $90 \%$ of hop moisture content at a relatively low temperature to maintain hop quality. Under this design objective, alternative costeffective and sustainable drying technologies were explored for small and medium-sized hop farms.

\subsection{Scientific design method}

To avoid "design by trial and error", the well-known scientific design method-quality function deployment (QFD), was applied to translate customer needs into measureable design characteristics. Customer (grower) needs were captured using discussions, interviews and surveys [5]. This understanding of the customer needs was then summarized in a product planning matrix or 'house of quality'. These matrices are used to translate higher level 'what's' or needs into lower level 'hows'-product requirements or technical characteristics to satisfy these needs.

As part of the QFD, the "house of quality" for the dryer is as shown in Figure 1. In the figure, the rows are the customer required quality, and the columns are the product development capabilities. As University of Vermont [6] and University of Maine [7] are the only universities who reported the integration of design of hop postharvest equipment into their engineering program. We also compared the opportunities between our dryer products with theirs on customer demands. 


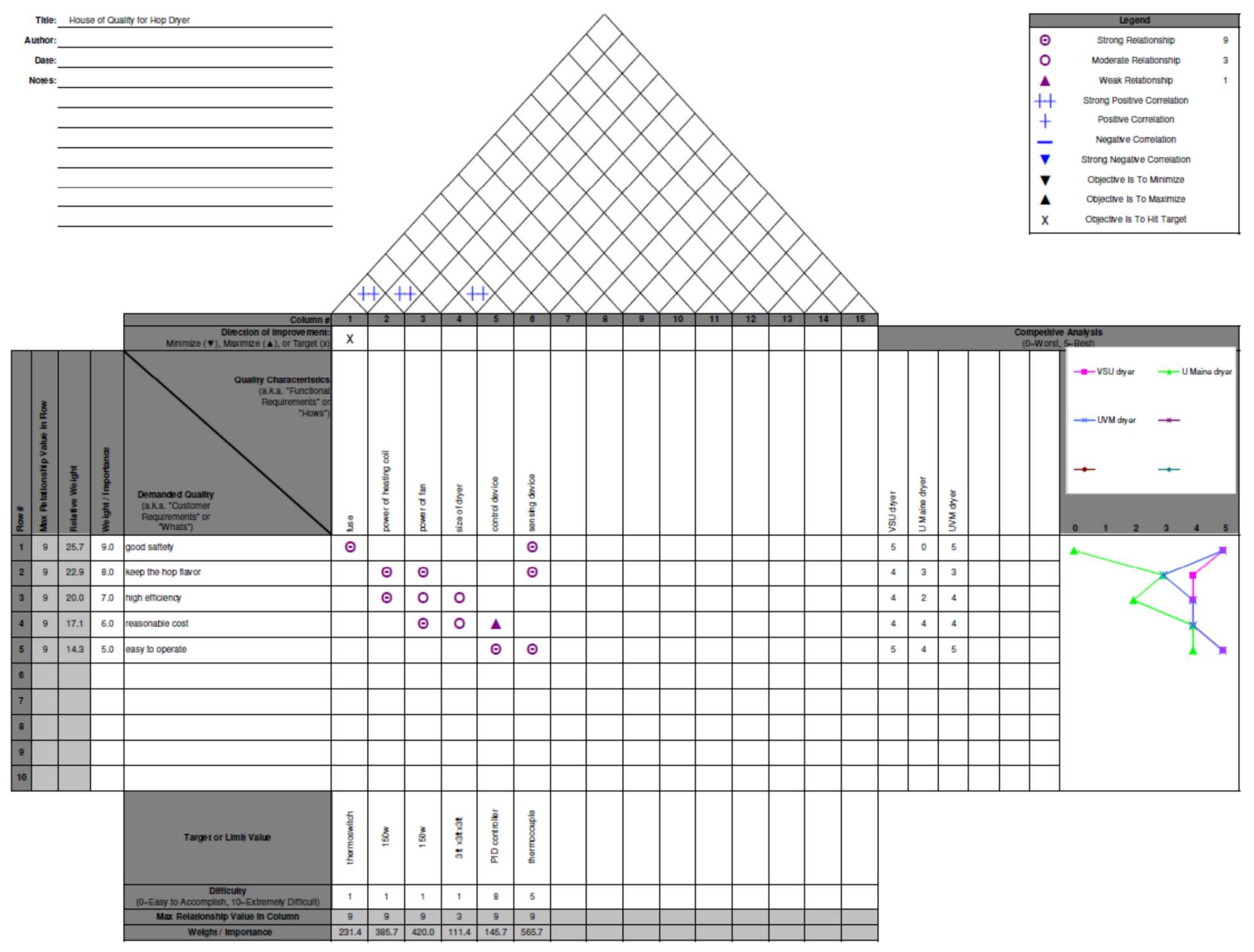

Figure 1. House of Quality for a Hop Dryer Design 


\subsection{Generate design concepts}

With the needs and potential improvement being identified, design concepts were generated by analogy with dryers that are being used in everyday life. Mainly, seven types of dryers were researched and tabulated as shown in Table 1.

Table 1 Product Research and Analogy [1]

\begin{tabular}{|c|c|c|}
\hline Type & Image & Functions \\
\hline Tumbler dryers & +2 & $\begin{array}{l}\text { Tumbler dryers continuously } \\
\text { draw in the cool, dry, ambient air } \\
\text { around them and heat it before } \\
\text { passing it through the load. }\end{array}$ \\
\hline & $\begin{array}{l}\text { http://ao.com/p/reviews/rc8015a-lg-condenser-tumble-dryer- } \\
\text { white-21752-18 }\end{array}$ & \\
\hline Spin dryers & 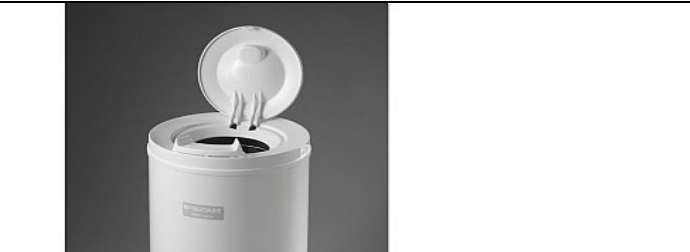 & $\begin{array}{l}\text { These centrifuge machines } \\
\text { simply spin their drums much } \\
\text { faster than a typical washer } \\
\text { could, in order to extract } \\
\text { additional water from the load. }\end{array}$ \\
\hline $\begin{array}{l}\text { Condenser } \\
\text { dryers }\end{array}$ & http://integratedtumbledryer.co.uk/best-condenser-tumble- & $\begin{array}{l}\text { Just as in a normal dryer, } \\
\text { condenser or condensation dryers } \\
\text { pass heated air through the load. } \\
\text { However, instead of exhausting } \\
\text { this air, the dryer uses a heat } \\
\text { exchanger to cool the air and } \\
\text { condense the water vapor into } \\
\text { either a drain pipe or a collection } \\
\text { tank }\end{array}$ \\
\hline $\begin{array}{l}\text { Heat pump } \\
\text { dryers }\end{array}$ & 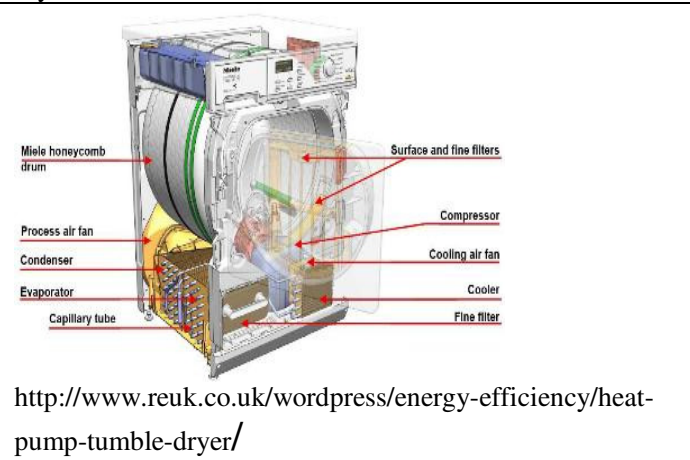 & $\begin{array}{l}\text { A closed-cycle heat pump clothes } \\
\text { dryer uses a heat pump to } \\
\text { dehumidify the processing air. }\end{array}$ \\
\hline
\end{tabular}




\begin{tabular}{|c|c|c|}
\hline $\begin{array}{l}\text { Mechanical } \\
\text { steam } \\
\text { compression } \\
\text { dryers }\end{array}$ & $\begin{array}{l}\text { http://www.homedepot.com/p/LG-Electronics-7-4-cu-ft- } \\
\text { Electric-Dryer-with-Steam-in-Wild-Cherry-Red-ENERGY- } \\
\text { STAR-DLEX3370R/205635538 }\end{array}$ & $\begin{array}{l}\text { A new type of dryer in } \\
\text { development, these machines are } \\
\text { a more advanced version of heat } \\
\text { pump dryers. Instead of using hot } \\
\text { air to dry the clothing, } \\
\text { mechanical steam compression } \\
\text { dryers use water recovered from } \\
\text { the clothing in the form of steam. }\end{array}$ \\
\hline $\begin{array}{l}\text { Solar clothes } \\
\text { dryer }\end{array}$ & https://www.houselogic.com/by-room/bathroom- & $\begin{array}{l}\text { The solar dryer is a box-shaped } \\
\text { stationary construction which } \\
\text { encloses a second compartment } \\
\text { where the clothes are held. It } \\
\text { uses the sun's heat without direct } \\
\text { sunlight reaching the clothes }\end{array}$ \\
\hline $\begin{array}{l}\text { Microwave } \\
\text { dryers }\end{array}$ & 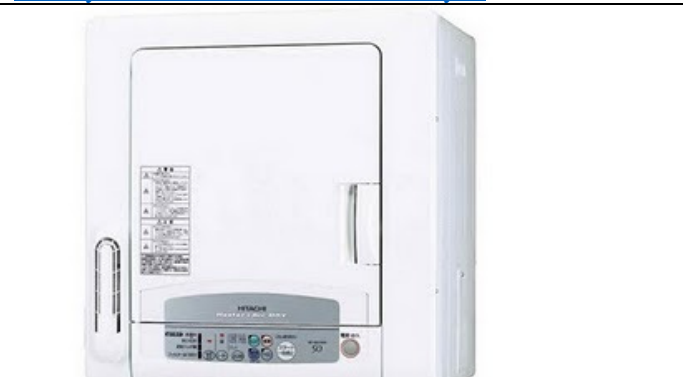 & $\begin{array}{l}\text { Japanese manufacturers have } \\
\text { developed highly efficient } \\
\text { clothes dryers that use } \\
\text { microwave radiation to dry the } \\
\text { clothes (though a vast majority of } \\
\text { Japanese air dry their laundry). }\end{array}$ \\
\hline
\end{tabular}

Due to the design constraints of time, budget, and difficulty etc., attempting to imitate all these concepts was not feasible. So this list was narrowed down with further research and by focusing on how these multiple types of dryers were powered. Electric and pneumatic drying were selected as the design concept. The final decision was made to create a $3 \mathrm{ft} \times 3 \mathrm{ft} \times 3 \mathrm{ft}$ crate with an airflow and electric drying system.

\subsection{Embody the design}

The final design is shown in Figure 2. For airflow, a fan was installed at the top of the dryer. This would bring air into the dryer and the air would exit through a vent at the bottom. The dryer casing is made of cedar wood, because cedar wood can withstand heat and since cedar wood is used in saunas, it was seen as the best option. A heat-reflective layer was also attached to the interior of the walls. Inside the drying space, we installed 2 shelves made of a coated mesh framed with cedar wood. A nickel-chrome wire powered by a 12 volt battery acted as a heating source. Internal temperature was measured and regulated with a thermocouple and a controller, respectively. 


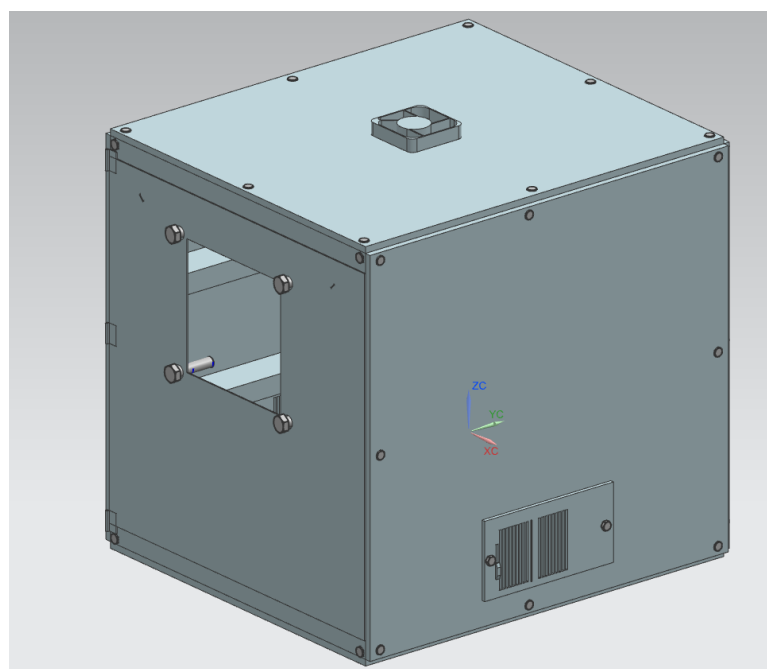

(a)

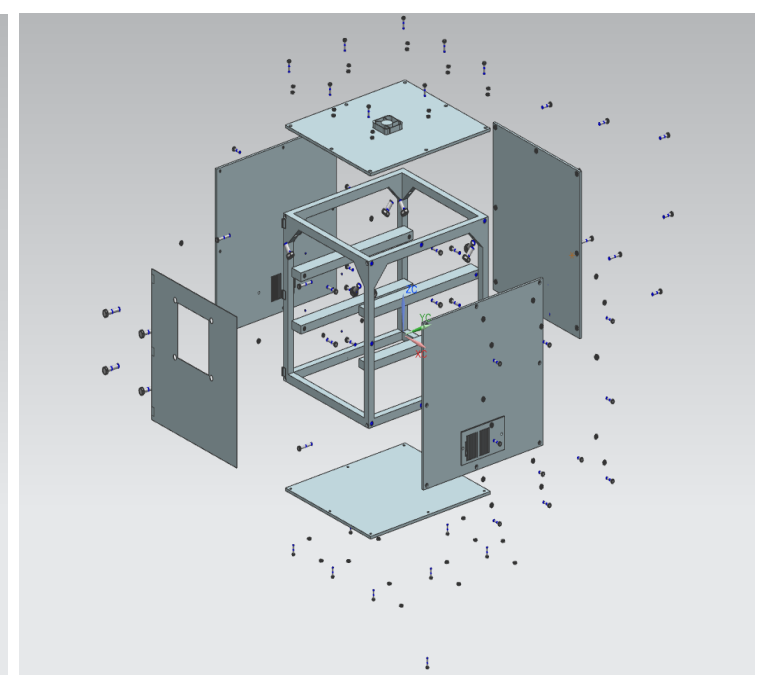

(b)

Figure 2 the Final Design for the Dryer, (a) Design Assembly, and (b) Explosion View of Assembly

\subsection{Analyze the design}

The engineering analysis was conducted from three aspects: 1) structural analysis, 2) flow analysis in the NX CAE environment, and 3) cost analysis for the prototype.

1) Structural analysis

A linear static force of 100-pounds to mimic the gravity of hops was applied on the dryer shelves. The stress analysis and displacement analysis is illustrated in Figure 3 (a) and (b).

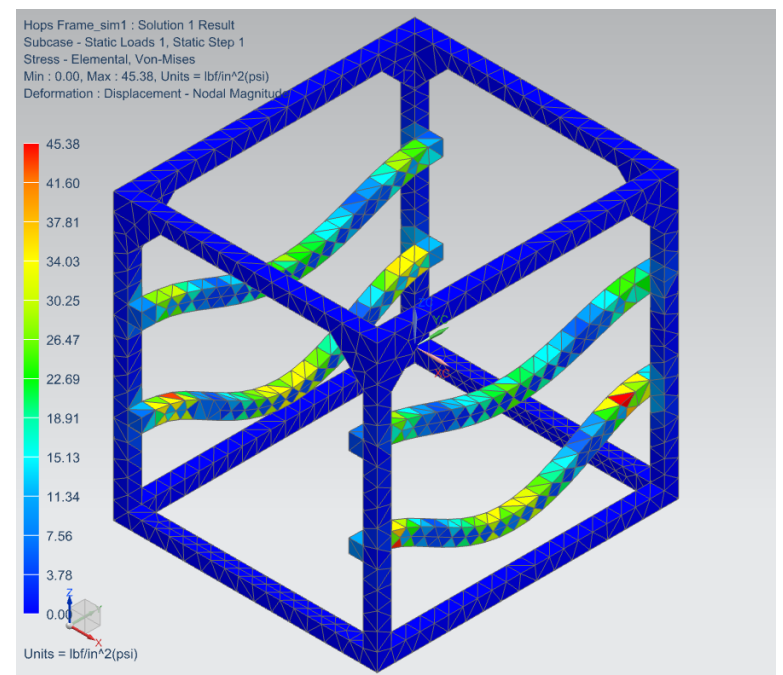

(a)

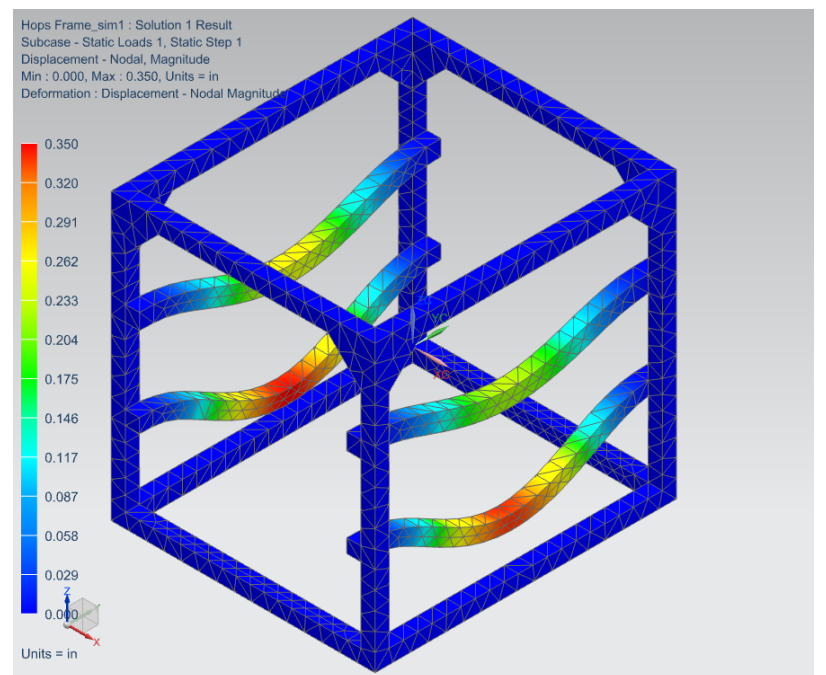

(b)

Figure 3 Stress Analysis (a) and Displacement Analysis (b) on the Dryer

2) Flow Analysis

The dryer can work in two modes: 1) with only the fan running to create circulation to dry the hops, or 2) with the fan and heater turned on to dry the hops. The fan was mounted on top of the dryer as illustrated in the Figure 1. The fan was represented by an inlet with volume flow of 20 $\mathrm{in}^{3} /$ second, the two sidewall ceiling vents were installed as the opening. The flow analysis is illustrated in Figure 4, while Figure 5 shows fluid velocity. 


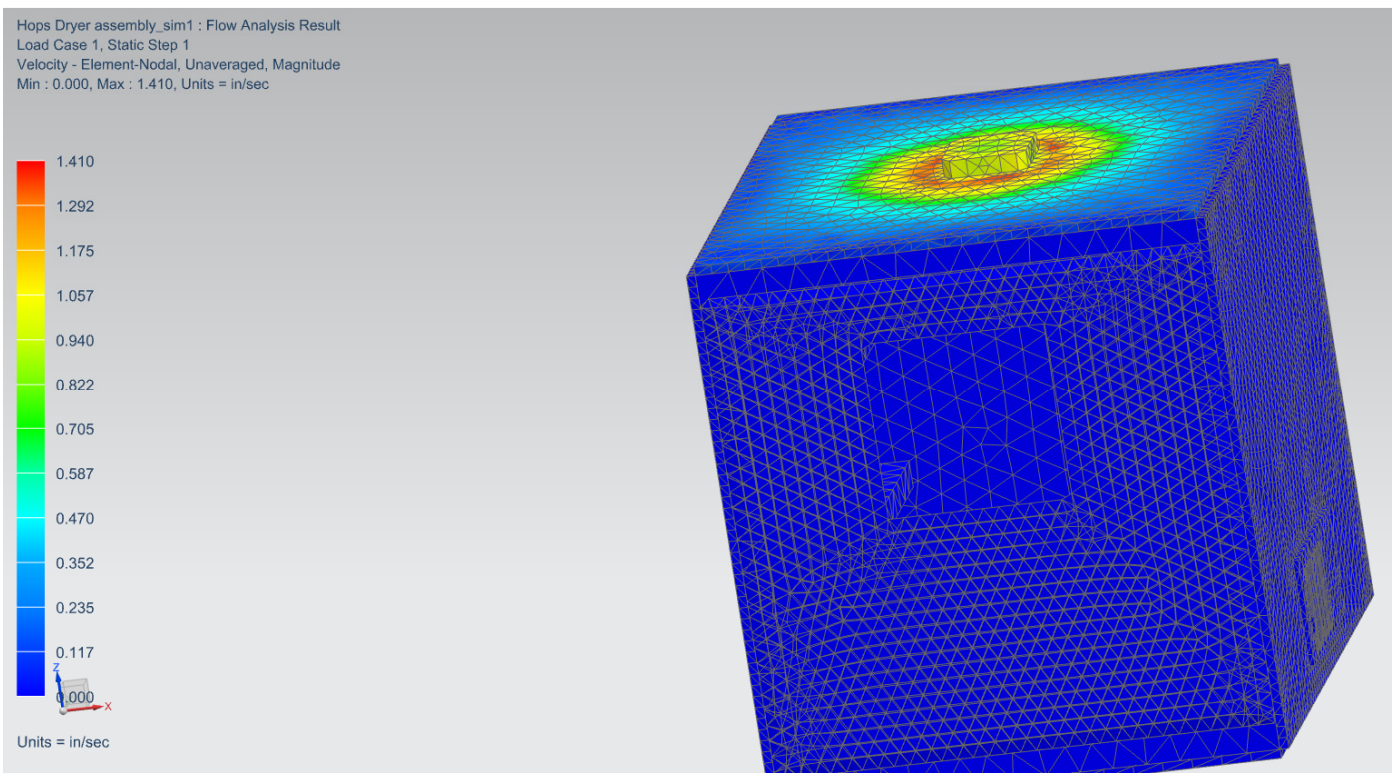

Figure 4 Flow Analysis of the Dryer

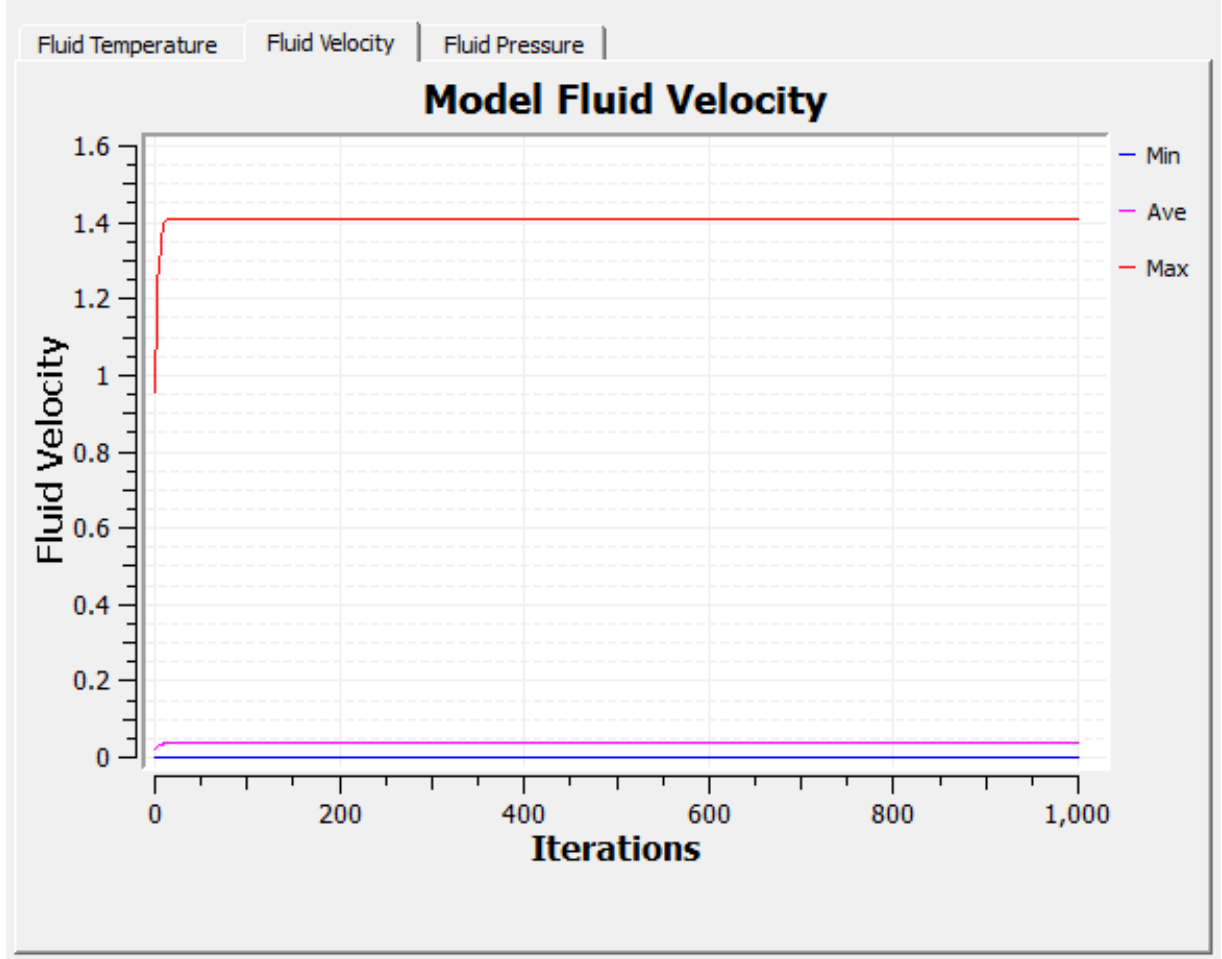

Figure 5 Fluid Velocity Analysis

\section{3) Cost analysis}

The students were further trained to analyze the cost for the prototype the design. The cost was mainly in form of labor and materials. The labor was estimated to be around 30 hours, and the material cost estimates are shown in Table 2. At the beginning of the project, the students were told that the budget limit is $\$ 500$. The material cost is within the budget range. 
Table 2 Material Cost Analysis for the Product Prototype

\begin{tabular}{|c|c|c|c|c|}
\hline Item Description & Model Number & $\begin{array}{c}\text { Unit } \\
\text { Price }(\$) \\
\end{array}$ & Qty. & $\begin{array}{c}\text { Cost } \\
(\$)\end{array}$ \\
\hline Door switch (DPST) & 91801-01 & 11.97 & 1 & 11.97 \\
\hline Controller & ETC-JLD612-A & 32.5 & 1 & 32.5 \\
\hline Relays & SSR057 & 13.95 & 2 & 27.98 \\
\hline Temperature sensor & Type K thermocouple & 17.99 & 1 & 17.99 \\
\hline Accord Sidewall/Ceiling Register, White & ABSWWH2104 & 7.3 & 2 & 14.6 \\
\hline ExpertPower 12 Volt 18 Ah Rechargeable Battery & EXP12180 & 31.3 & 1 & 31.3 \\
\hline Suncourt Transfer Fan, 7-5/8-Inch & TW108 ThruWall & 52.95 & 1 & 52.95 \\
\hline 10ft nichrome wire & & $\begin{array}{l}36.22 / 10 \\
\mathrm{ft}\end{array}$ & $10 \mathrm{ft}$ & 36.22 \\
\hline Wood Boards and Beams & & $\begin{array}{l}18.89 / \\
\text { board }\end{array}$ & 5 & 94.45 \\
\hline 100-count Nuts and Bolts & & 10.16 & 1 & 10.16 \\
\hline Reflectix 16 in. x $100 \mathrm{ft}$. & & 40.36/roll & 3 & 121.08 \\
\hline \multicolumn{4}{|l|}{ Total Cost } & 451.2 \\
\hline
\end{tabular}

\subsection{Prototyping the design}

Because there was no TA or machinist assistance in the course, the prototype process was designed as Maker activities for students. The instructor provided instructions on using the tools and safety training in the makerspace. The students made the prototype by themselves and shared their work and processes with each other. The instructor monitored the safety of operations when students were working in the machine shop. The maker activities provided students with an excellent opportunity to bring their designs in paper to life by actually fabricating them. It also created an ideal cooperative environment for them to deliver the tasks together.

During prototyping, students learned how to select the right tools of 1) band saws, 2) jig saws, 3) power screw driver, 4) stapler gun, and 5) fasteners to make the parts and assemble the product. Also, they practiced the observation of safety rules in the machine shop. The fabrication process for each part is illustrated in Figure 6. The whole assembly of the dryer is illustrated in Figure 7.

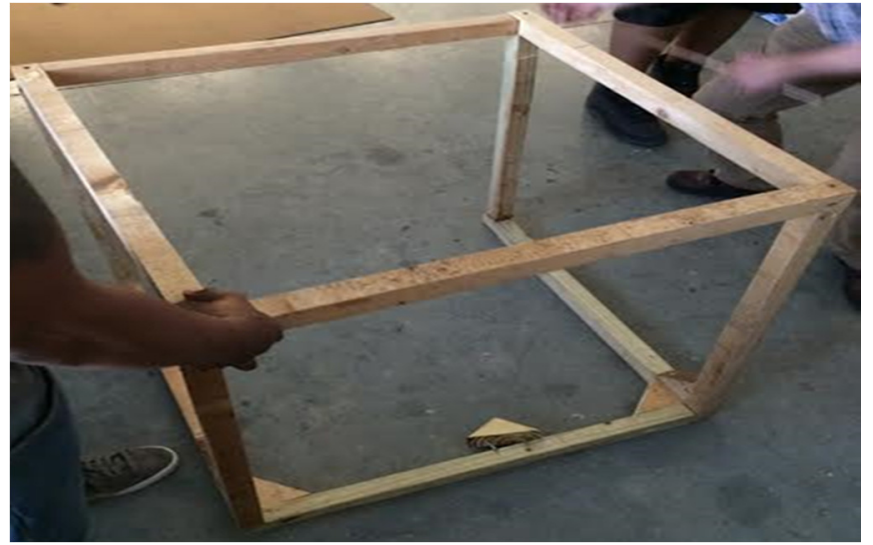

(a)

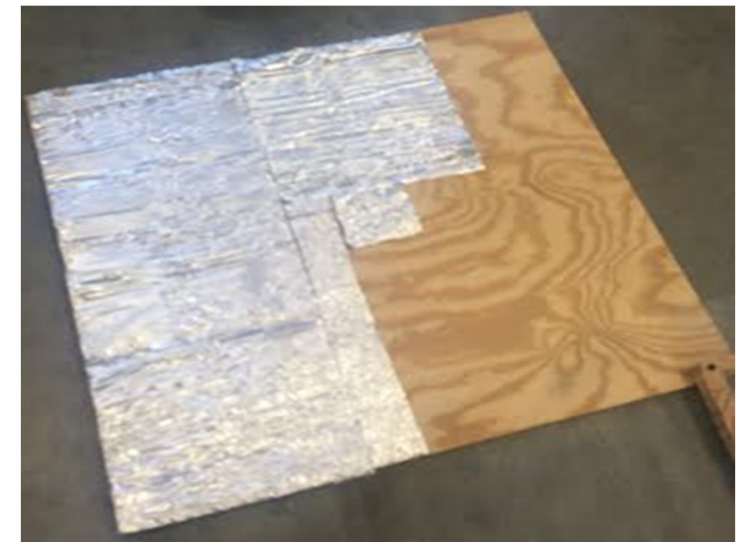

(c) 


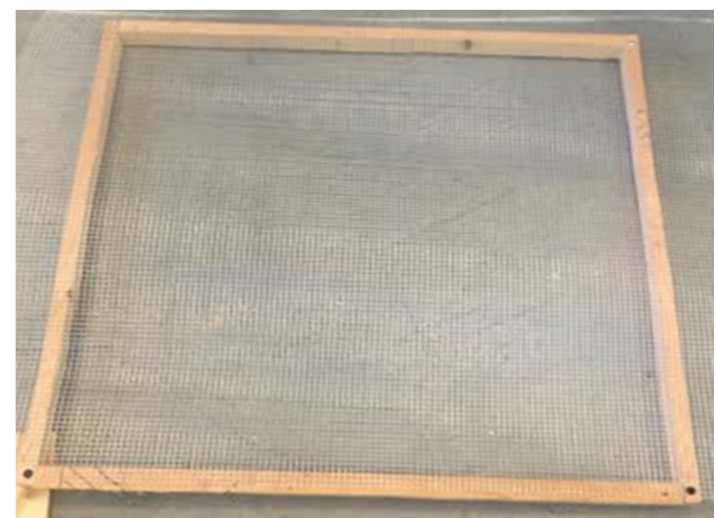

(b)

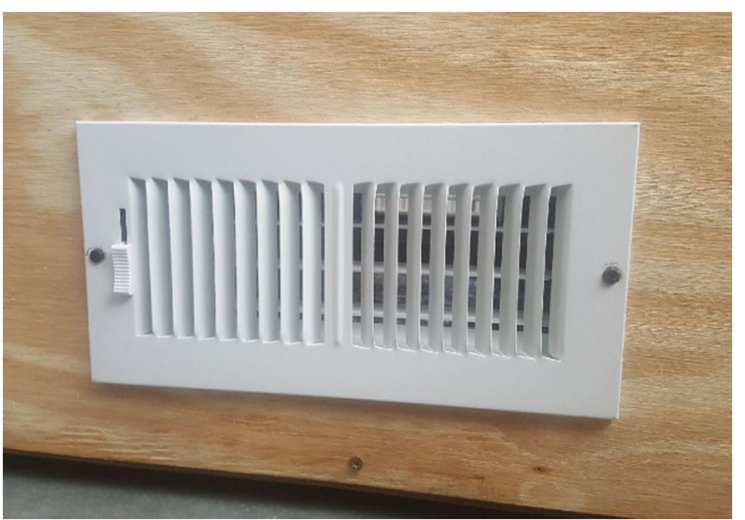

(d)

Figure 6 Fabrication of Parts (a) Frame, (b) Shelves, (c) Sides and Back, (d) Sides with Vent

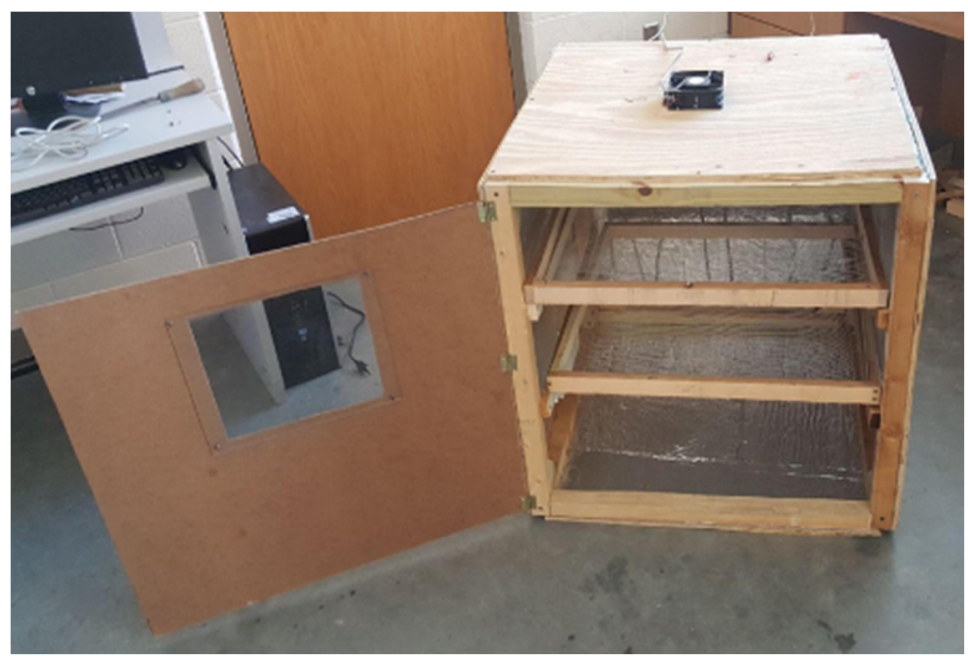

Figure 7 the Assembled Dryer Prototype

\section{Learning Outcome Evaluation}

The learning outcome evaluation was through direct and indirect assessment. Direct assessment was conducted by the faculty to evaluate students' performance on the proposed tasks and study objectives. Indirect assessment was accomplished through surveys of student feeling on mastery of the engineering and non-engineering skills.

(1) Direct Assessment

Direct assessment was based on the quality of the work contents, reports, and presentations in the three design phases. The grading scheme for the course is as shown below (Table 3). To help student with good engineering habits, they were required to keep an individual diary to track the work that they had done. There were three students involved in the design and prototyping of the dryer. Direct assessment results for the three students are summarized in Table 4. 


\begin{tabular}{|c|c|c|}
\hline Phase & Item & Points \\
\hline \multirow{3}{*}{$\begin{array}{l}\text { Needs } \\
\text { definition } \\
\text { and concepts } \\
\text { generation }\end{array}$} & $\begin{array}{l}\text { Tasks in Identify needs and concepts: Phase I technique tasks have } \\
\text { been described in Section } 2\end{array}$ & 10 \\
\hline & $\begin{array}{l}\text { Report: describe the current practice of the product you are going to } \\
\text { design. Clearly identify the gap between customer needs and } \\
\text { existing designs, its significance, and potential influencing factors, } \\
\text { preliminary analysis, and generate concept design based on the gap }\end{array}$ & 5 \\
\hline & Presentation: summary Phase I technique tasks and achievements & 5 \\
\hline \multirow{3}{*}{$\begin{array}{l}\text { Embody } \\
\text { design and } \\
\text { analysis }\end{array}$} & $\begin{array}{l}\text { Tasks in Design model and analysis: Phase II technique tasks have } \\
\text { been described in Section } 2\end{array}$ & 25 \\
\hline & $\begin{array}{l}\text { Report: describe: 1) the detailed design and assembly for design } \\
\text { concepts, 2) the right material selection for design solution, and 3) } \\
\text { engineering analysis to understand the design parameters' effect in } \\
\text { the functions of prototype. }\end{array}$ & 5 \\
\hline & Presentation: summary Phase II technique tasks and achievements & 5 \\
\hline \multirow{3}{*}{$\begin{array}{l}\text { Final } \\
\text { prototype and } \\
\text { report }\end{array}$} & $\begin{array}{l}\text { Prototype and experiment: Phase III technique tasks have been } \\
\text { described in Section } 2\end{array}$ & 15 \\
\hline & $\begin{array}{l}\text { Report: A comprehensive and self-contained report. This report will } \\
\text { summarize the work in the previous two phase to document the } \\
\text { challenges, solutions and achievements in the design and } \\
\text { implementation course. Experiment data collection and analysis will } \\
\text { be presented to solidly support your achievements. A reader must be } \\
\text { able to get a complete picture of the product and what you have } \\
\text { done to design the product. }\end{array}$ & 10 \\
\hline & $\begin{array}{l}\text { Presentation: summary technique tasks and achievements in the } \\
\text { whole design process }\end{array}$ & 5 \\
\hline \multicolumn{2}{|l|}{ Attendance } & 10 \\
\hline \multicolumn{2}{|c|}{ Individual engineering diary } & 5 \\
\hline
\end{tabular}

Table 4 Direct Assessment of Student Learning

\begin{tabular}{|c|c|c|c|c|c|c|c|c|c|c|}
\hline \multirow[t]{2}{*}{ Student } & \multicolumn{3}{|c|}{ Phase I } & \multicolumn{3}{|c|}{ Phase II } & \multicolumn{3}{|c|}{ Phase III } & \multirow{2}{*}{$\begin{array}{l}\text { Attendance } \\
\text { and } \\
\text { engineering } \\
\text { diary }\end{array}$} \\
\hline & Needs & $\begin{array}{l}\text { Written } \\
\text { report }\end{array}$ & $\begin{array}{c}\text { Oral } \\
\text { presentation }\end{array}$ & $\begin{array}{c}\text { Design } \\
\text { details/ } \\
\text { analysis }\end{array}$ & $\begin{array}{l}\text { Written } \\
\text { report }\end{array}$ & $\begin{array}{c}\text { Oral } \\
\text { presentation }\end{array}$ & Prototype & $\begin{array}{l}\text { Final } \\
\text { report }\end{array}$ & $\begin{array}{c}\text { Final } \\
\text { presentation }\end{array}$ & \\
\hline $\mathrm{A}$ & 9 & 5 & 5 & 23 & 5 & 5 & 14 & 10 & 5 & 15 \\
\hline B & 9 & 5 & 5 & 23 & 5 & 5 & 14 & 10 & 5 & 15 \\
\hline $\mathrm{C}$ & 9 & 5 & 5 & 23 & 5 & 5 & 14 & 10 & 4 & 15 \\
\hline
\end{tabular}

(2) Indirect Assessment

Survey was conducted among the students upon finishing the course. They were asked about their competencies as a result of the learning experiences in this course. Student survey results are tabulated in Table 5. Figures in columns indicate the number of students who believe they are competent in that category. From indirect assessment results, students involved in this project believed they had achieved learning objectives in this class. The students also witnessed that "Throughout this project I learned hands on design development skills. This project has showed me the importance of communication, scheduling, team work, and an understanding of the research 
progress. This was a great hands-on experience in addition to class in general. I will carry these skills through the rest of my collegiate and professional career" [1].

Table 5 Student Indirect Assessment Survey Results

\begin{tabular}{|l|l|l|l|l|}
\hline \multicolumn{1}{|c|}{ COURSE OBJECTIVES } & $\begin{array}{l}\text { STRONGLY } \\
\text { AGREE }\end{array}$ & AGREE & DISAGREE & $\begin{array}{l}\text { STRONGLY } \\
\text { DISAGREE }\end{array}$ \\
\hline $\begin{array}{l}1 \text { The ability to apply the knowledge and } \\
\text { tools learned in the undergraduate } \\
\text { curriculum. }\end{array}$ & 3 & & & \\
\hline $\begin{array}{l}2 \text { The ability to use constraint based } \\
\text { engineering design process to generate } \\
\text { design options. }\end{array}$ & 3 & 1 & & \\
\hline $\begin{array}{l}3 \text { The ability to design and conduct } \\
\text { engineering experiments in support of } \\
\text { design or development using literature } \\
\text { search. }\end{array}$ & 2 & 1 & & \\
\hline 4 An ability to select appropriate tools. & 2 & & \\
\hline $\begin{array}{l}\text { 5 The ability to form a team and to } \\
\text { participate effectively, communicating } \\
\text { clearly and managing the task oriented } \\
\text { project. }\end{array}$ & 3 & & & \\
\hline $\begin{array}{l}\text { 6 Effective individual and team } \\
\text { communication skills, including task and } \\
\text { schedule development using the Microsoft } \\
\text { Office software. }\end{array}$ & 3 & & & \\
\hline $\begin{array}{l}\text { 7.The ability to prepare reports and } \\
\text { presentations to disseminate the results of } \\
\text { the project }\end{array}$ & 2 & & & \\
\hline
\end{tabular}

\section{Conclusion and Future Directions}

The cooperation between the engineering and agriculture programs provided a real design problem for the engineering students. The inputs from the agriculture researchers enlightened the engineering students on the customer needs and design priorities. The students developed a clear image of applying manufacturing engineering knowledge to solve problems in agriculture.

The proposed teaching methodology filled the design education gap through innovative design theories of quality function deployment (QFD). All the approaches to fill the knowledge and educational gaps can be well integrated as 'Maker' activities for engineering students. Students were involved in the activities of design/prototyping, data collection and analysis, and outreach through the inter-disciplinary project. The project engaged students in the interdisciplinary learning of engineering and agricultural principles. The direct assessment and indirect assessment results illustrated that the joint activities between agriculture and engineering can provide a realworld problem for students to address. The teaching strategies for this design course also effectively helped students to achieve the desired learning outcome. The engineering approaches and analysis procedures in this project enriches the course content for 1) Product Design, 2) Manufacturing Processes, 2) Thermal Engineering, and 4) Manufacturing Automation. 


\section{Acknowledgement}

The financial support received through the VSU CAREO seed grant and VSU Engineering and Computer Science Department are deeply appreciated. The hard work from the dryer group in the VSU MANE 450 in Spring 2017 is thankfully acknowledged.

\section{Reference}

[1] D. Gilliam, J. Williams, and Q. Harvey, “The Design and Implementation of a Hops Dryer", MANE 450 Project Final Report, Virginia State University, Spring 2017.

[2] Engineering Student Handbook, Virginia State University, 2013

[3] J. Cagan and C. M. Vogel, Creating Breakthrough Products-Innovation from Product Planning to Program Approval, Prentice Hall, 2002.

[4] L. Siegle, H. Scoggins, S. Driver, and D. Kistler, "Hops in Virginia-2014 Grower Survey", Virginia Cooperative Extension, 2015.

[5] J. Tapke, A. Muller, G. Johnson, and J. Siec, "House of Quality: Steps in Understanding the House of Quality". IE 361. Iowa State University

[6] http://www.uvm.edu/extension/cropsoil/hopequipment

[7] https://extension.umaine.edu/agriculture/sustainable-agriculture/profile-sustainable-

hopproduction/ 